\title{
PENGARUH PENGAWASAN DAN DISIPLIN KERJA TERHADAP PRODUKTIVITAS KERJA KARYAWAN PADA PT. PLN (PERSERO) RAYON AMBON KOTA
}

\author{
N. E. Maitimu \\ Program Studi Teknik Industri, Fakultas Teknik Universitas Pattimura, Ambon \\ V. O. Lawalata \\ Program Studi Teknik Industri, Fakultas Teknik Universitas Pattimura, Ambon \\ Tedi Hariadi \\ PLN Wilayah Maluku dan Maluku Utara, Ambon
}

\begin{abstract}
ABSTRAK
Arah dan tujuan bisnis menjadi pedoman dasar bagi PT PLN (Persero) untuk meningkatkan produktivitaskerja sesuai harapan pemegang saham dan pelanggan. Oleh karena itu, pengawasan dan penerapan disiplin kerja karyawan cenderung dapat memberikan tingkat produktivitas kerja karyawan yang baik. Untuk itu, penelitian ini diselenggarakan dengan tujuan untuk membuktikan signifikansi pengaruh pengawasan dan disiplin kerja terhadap produktivitas kerja karyawan pada PT. PLN (Persero) Rayon Ambon Kota. Penelitian ini menggunakan kuesioner sebagai alat pengumpulan data yang disebarkan kepada 80 responden (karyawan) sebagai sampel. Metode analisis data yang dipakai adalah Partial Least Square (PLS) yang diolah menggunakan aplikasi SmartPLS 2.0. Hasil penelitian menyimpulkan bahwa Pegawasan Kerja tidak memberikan pegaruh yang signifikan terhadap Produktivitas Kerja, sedangkan Disiplin Kerja memberikan pegaruh positif yang signifikan terhadap Produktivitas Kerja karywan PT. PLN (Persero) Rayon Ambon Kota. Disiplin Kerja dapat menerangkan 35,3117\% dari keragaman Produktivitas Kerja karyawan PT. PLN (Persero) Rayon Ambon Kota, dimana sisanya dipengaruhi oleh variabel lain diluar model penelitian ini.
\end{abstract}

Kata Kunci : Pengawasan, Disiplin Kerja, Produktivitas Kerja.

\begin{abstract}
The direction and business objectives become the basic guidelines for PT PLN (Persero) to increase work productivity in accordance with the expectations of shareholders and customers. Therefore, the implementation of supervision and work discipline tends to provide a good level of employee productivity. For this reason, a study was conducted that aims to prove the significant effects of supervision and work discipline on employee work productivity at PT. PLN (Persero) Rayon Kota Ambon. This study uses questionnaires as a data collection tool that is distributed to 80 respondents (employees) as the samples. The data analysis method is Partial Least Square (PLS) which processed by the SmartPLS 2.0. The results of the study we conclude that Job Supervision does not have a significant effect on Work Productivity, while Work Discipline has it. Work Discipline can explain $35.3117 \%$ of the diversity of Employee Work Productivity of PT. PLN (Persero) Ambon City Rayon, where the rest is influenced by other variables outside this research model.
\end{abstract}

Keywords: Supervision, Work Discipline, Work Productivity.

\section{PENDAHULUAN}

Perusahaan yang didirikan mempunyai harapan bahwa kelak akan mengalami perkembangan yang sangat pesat dalam lingkup usaha dari perusahaan tersebut. Perusahaan menginginkan tercapainya produktivitas yang tinggi dalam bidang kerjanya. Dengan produktivitas yang tinggi maka perusahaan akan memperoleh keuntungan atau profit. Perusahaan adalah penggerak perekonomian bangsa Indonesia karena dalam mencapai tujuannya mencari laba, harus memenuhi aneka ragam kebutuhan masyarakat. Perusahaan sebagai suatu organisasi yang menggunakan dan mengkoordinir sumber-sumber ekonomi untuk memproduksi barang dan jasa di dorong untuk meningkatkan produktivitas usaha sehingga nantinya mampu memaksimalisasikan laba untuk bertahan dalam jangka panjang.

Produktivitas kerja adalah perbandingan antara hasil yang dicapai dengan peran serta tenaga kerja persatuan waktu. (Melayu S.P Hasibuan 2003:20). Produktivitas kerja merupakan motif ekonomi untuk 
memperoleh hasil maksimal dengan biaya tertentu, dimana dalam pelaksanaannya produktivitas banyak terletak pada faktor sebagai pelaksana kegiatan perusahaan yaitu, para anggota, karyawan atau pekerja. Jadi faktor manusia memegang peranan penting dalam mencapai hasil sesuai dengan tujuan perusahaan, karena betapapun sempurnanya peralatan kerja tanpa adanya tenaga manusia tidak akan berhasil memproduksi barang dan jasa sesuai dengan tujuan yang ingin dicapai (Agusty 2006:112).

Dalam penelitian ini produktivitas kerja yang di maksud adalah rasio atau perbandingan antara hasil yang dicapai oleh PT. PLN (Persero) Rayon Ambon Kota dalam memperbaiki dan menyelesaikan pekerjaan yang ada guna mencapai hasil yang terbaik untuk perusahaan dalam satuan waktu. Pelaksanaan produktivitas kerja pada PT. PLN (Persero) Rayon Ambon Kota berjalan kurang baik dan pekerjaan tersebut tidak selesai dengan waktu yang di tentukan karna kurangnya pengawasan kerja dan disiplin kerja sehingga pekerjaan tersebut masih banyak tertunda.

Pada setiap perusahaan memerlukan pengawasan dari pihak manajer. Pengawasan ini dilakukan oleh manajer sebagai suatu usaha membandingkan apakah yang dilakukan sesuai dengan rencana yang ditetapkan. Hal ini berarti juga pengawasan merupakan tindakan atau kegiatan manajer untuk mengusahakan agar pekerjaan terlaksana sesuai dengan rencana yang ditetapkan atau hasil kerja yang dikehendaki.

Pada perusahan PT. PLN (Persero) Rayon Ambon Kota, faktor pengawasan kerja dan disiplin kerja merupakan faktor yang penting bagi perusahaan dalam mencapai tujuan yang telah ditetapkan. Oleh karena itu manajer harus melakukan pengawasan kerja yang efektif, maka dengan sendirinya disiplin kerja karyawanpun akan baik sehingga karyawan bisa mencapai prestasi kerja yang optimal dalam bentuk produktivitas kerja. PT. PLN (Persero) Rayon Ambon Kota merupakan salah satu perusahaan yang bergerak dibidang jasa (Listrik), yang telah banyak memberikan kontribusi terhadap pendapatan nasional. Untuk melengkapi data awal, maka peneliti melakukan penelitian awal yang dilakukan dalam bentuk wawancara dengan Manejer PT. PLN (Persero) Rayon Ambon Kota. Hasil wawancara menunjukan bahwa pengawasan sudah diterapkan oleh manejer PT. PLN (Persero) Rayon Ambon Kota sudah berjalan dengan baik. Namun dalam pelaksanaannya, pengawasan yang diberikan oleh pemimpin sebatas melihat laporan-laporan kerja dari karyawan sehingga tindakan koreksi tidak dapat dilakukan secara langsung pada saat aktivitas pekerjaan berlangsung sehingga mempengaruhi tingkat produktivitas kerja karyawan dalam menyelesaikan tugas-tugas yang diberikan oleh pemimpin. Adapun jumlah karyawan pada PT. PLN (Persero) Rayon Ambon Kota berjumlah 80 orang.

Fakta yang ada di lapangan menunjukkan adanya gejala-gejala yang cenderung terjadi penurunan produktivitas kerja para karyawan bagian pemutusan. Hal ini disebabkan kurangnya pengawasan yang efektif dan kurangnya sikap disiplin kerja karyawan. Untuk itu dalam meningkatkan produktivitas kerja karyawan manajer harus melakukan pengawasan yang baik sehingga sikap disiplin kerja dalam diri karyawan muncul. Dengan demikian karyawan akan mengerjakan pekerjaan dengan penuh tanggungjawab dan disiplin kerja yang tinggi. Penelitian ini bertujuan untuk menganalisis pengaruh pengawasan kerja terhadap produktivitas kerja karyawan PT. PLN (Persero) Rayon Ambon Kota dan unutk menganalisis pengaruh disiplin kerja terhadap produktivitas kerja karyawan pada PT. PLN (Persero) Rayon Ambon Kota;

\section{LANDASAN TEORI \\ Pengertian Pengawasan Kerja}

Dalam pengertian awal, pengawasan kerja dapat diartikan sebagai perubahan untuk melihat dan memonitor terhadap orang agar ia berbuat sesuai dengan kehendak yang telah ditentukan sebelumnya. Sedangkan dalam ilmu manajemen, pengawasan kerja adalah merupakan salah satu fungsi manajemen yang merupakan faktor penentu bagi kelangsungan hidup suatu organisasi.

Pengawasan kerja mempunyai arti penting bagi setiap perusahaan. Pengawasan kerja bertujuan agar hasil pelaksanaan pekerjaan diperoleh secara berdaya guna (efisien) dan berhasil guna (efektif), sesuai dengan rencana yang telah ditetapkan sebelumnya. Pengawasan kerja adalah kegiatan manejer yang mengusahakan agar pekerjaan-pekerjaan terlaksana sesuai dengan rencana yang ditetapkan dan atau hasil yang dikehendaki (Lubis, 2005:154).

Menurut Manullang, (2002:173) pengawasan kerja adalah suatu proses untuk menetapkan pekerjaan apa yang sudah dilaksanakan, menilainya dan mengoreksi bila perlu dengan maksud supaya pelaksanaan pekerjaan sesuai dengan rencana-rencana semula. Pendapat ahli lain, pengawasan adalah suatu usaha sistimatik untuk menetapkan standar pelaksanaan kerja dengan tujuan-tujuan perencanaan, merancang sistem informasi umpan balik, membandingkan kegiatan nyata dengan standar yang telah ditetapkan sebelumnya, menentukan dan mengukur penyimpangan-penyimpangan serta mengambil tindakan koreksi yang diperlukan unrtuk menjamiin bahwa semua sumber daya perusahaan dipergunakan dengan cara 
paling efektif dan efesien dalam pencapaian tujuan-tujuan perusahaan (Handoko, 2004:360-361).Dari beberapa pendapat tersebut di atas dapat disimpulkan bahwa pengawasan merupakan suatu kegiatan yang mengusahakan agar pekerjaan terlaksana sesuai dengan rencana dan standar yang telah ditetapkan serta hasil kerja yang dikehendaki.

Adapun maksud dari pengawasan kerja adalah untuk mencegah atau untuk memperbaiki kesalahan, penyimpangan, ketidaksesuaian dan lainnya yang tidak sesuai dengan tugas dan wewenang yang telah ditentukan. Adapun tujuan pengawasan menurut Kadarman dan Udaya (2001:159) Adalah menemukan kelemahan dan kesalahan untuk kemudian dikoreksi dan mencegah pengulangannya. Menurut Manullang (2002:74), tujuan utama dari pengawasan adalah agar apa yang direncanakan menjadi kenyataan.

Menurut Handoko (2014:361-362), ada tiga tipe pengawasan yaitu pengawasan pendahuluan, pengawasan concurrent, dan pengawasan umpan balik. Ketiga bentuk pengawasan tersebut sangat berguna bagi manajemen, khususnya pengawasan pendahuluan dan pengawasan concurrent, dimana memungkinkan manajemen untuk membuat tindakan koreksi dan tetap mencapai tujuan. Akan tetapi perlu dipertimbangkan disamping kegunaan dua bentuk pengawasan yaitu :

a. Biaya keduanya mahal;

b. Banyaknya kegiatan tidak memungkinkan dirinya dimonitor secara terus-menerus;

c. Pengawasan yang berlebihan akan menjadikan produktivitas berkurang.

Teknik pengawasan adalah cara melaksanakan pengawasan dengan terlebih dahulu menentukan titik-titik pengawasan sehingga dapat ditarik suatu kesimpulan mengenai keadaan keseluruhan kegiatan organisasi. Teknik pengawasan menurut Manullang 2002:54 sebagai berikut:

1. Peninjauan pribadi

2. Pengawasan melalui laporan lisan

3. Pengawasan melalui hal-hal yang bersifat khusus, didasarkan kekecualian atau control by exeption.

Dalam proses pengawasan secara umum menurut Handoko, (2014:26) terdiri dari tiga faktor atau indikator atau fase, yaitu:

1. Penetapan standar kerja adalah waktu yang di tentukan untuk memulai dan menyelesaikan suatu kegiatan (jadwal kerja).

2. Pengukuran hasil kerja yaitu, tindakan memeriksa hasil kerja yang di laksanakan oleh seluruh karyawan apakah sesuai dengan tujuan yang di tentukan.

3. Tindakan koreksi adalah pemberian solusi yang di berikan pimpinan dalam memperbaiki kesalahan atau kendala pada saat pelaksanaan kegiatan.

\section{Konsep Disiplin Kerja}

Menurut Simamora (2004:610), "Pada umumnya disiplin yang baik terdapat apabila karyawan datang ke kantor atau perusahaan dengan teratur dan tepat pada waktunya, apabila mereka berpakaian serba baik pada tempat pekerjaannya, apabila menggunakan bahan-bahan dan perlengkapan dengan hatihati, apabila mereka menghasilkan jumlah dan kualitet pekerjaan yang memuaskan, dan mengikuti cara kerja yang ditentukan oleh perusahaan dan apabila menyelesaikan dengan semangat yang baik". Disiplin merupakan keadaan yang menyebabkan atau memberikan dorongan kepada karyawan untuk berbuat dan melakukan segala kegiatan sesuai dengan norma-norma atau aturan-aturan yang telah ditetapkan.

Pengertian disiplin kerja adalah suatu ketaatan karyawan terhadap suatu aturan atau ketentuan yang berlaku dalam suatu perusahaan atas dasar adanya kesadaran atau keinsyafan bukan adanya unsur paksaan (Sinungan 2005:146). Menurut AS. Moenir (dalam Tohardi, 2002:393), disiplin adalah sendiri adalah ketaatan terhadap aturan. Sementara disiplinisasi adalah usaha yang dilakukan untuk menciptakan keadaan disuatu lingkungan kerja yang tertib, berdaya guna dan berhasil guna melalui suatu sistem pengaturan yang tepat.

Disiplin kerja dapat timbul dalam diri sendiri dan karena adanya perintah (GR.Terry dalam Winardi, 2007:218), membagi jenis disiplin menjadi 2, yaitu :

1. Disiplin yang ditimbulkan dari diri sendiri (self imposed disipline)

2. Disiplin berdasarkan perintah (command disipline).

Kegiatan pendisiplinan itu terdiri dari :

a. Disiplin Preventif

b. Disiplin korektif

Menurut Hasibuan (2007:194) pada dasarnya banyak indikator yang mempengaruhi tingkat kedisiplinan seorang karyawan, di antaranya Ketaatan, kesetiaan dalam melaksanakan pekerjaan, Disiplin waktu, Semangat Kerja, dan Tanggung Jawab. 


\section{Konsep Produktivitas Kerja}

Istilah produktivitas muncul pertama kali pada tahun 1966 dalam suatu masalah yang disusun oleh sarjana ekonomi Perancis bernama "Quesnay" (pendiri aliran phisiokrat), tetapi menurut Walter Aigner, dalam karyanya "Motivation andAwareness", filosofi, dan spirit tentang produktivitas, sudah ada sejak mulai peradaban manusia karena makna dari produktivitas adalah keinginan (the will) serta upaya (effort) manusia untuk selalu meningkatkan kualitas kehidupan dan penghidupan disegala bidang (Dinas Perburuhan Jatim dalam Sonny, 2003:23).

Menurut Simanjuntak (2005:26), produktivitas kerja pegawai mengandung pengertian adanya kemampuan pegawai untuk dapat menghasilkan barang atau jasa yang dilandasi sikap mental bahwa hari ini harus lebih baik dari hari kemarin, hari esok harus lebih baik dari hari ini. Sikap kerja yang demikian ini akan tetap melekat dalam diri pegawai yang memiliki produktivitas kerja yang tinggi. Penilaian terhadap produktivitas kerja pegawai dapat diukir melalui pelaksanaan kerja yang relatif baik, sikap kerja, tingkat keahlian dan disiplin kerja. Dan untuk mengukur produktivitas kerja pegawai itu sendiri harus mencakup aspek kuantitas dan kualitas pekerjaannya.

Peningkatan produktivitas tenaga kerja merupakan hal yang sangat penting dalam suatu perusahaan. Wana Nusa dalam Sumarsono Sonny (2003:63) menyatakan bahwa pendidikan, keterampilan, disiplin, motivasi, sikap dan etika kerja, gizi dan kesehatan, tingkat penghasilan, jaminan sosial, lingkungan dan iklim kerja, hubungan industrial, teknologi, sarana produksi, manajemen dan kesempatan berprestasi merupakan faktor-faktor yang mempengaruhi tingkat produktivitas kerja karyawan. Payaman J. Simanjuntak dalam Sumarsono Sonny (2009:169), juga mendefinisikan faktor yang mempengaruhi produktivitas karyawan perusahaan yang digolongkan pada tiga kelompok, yaitu:

1. Kualitas dan kemampuan fisik karyawan

2. Sarana pendukung, untuk meningkatkan produktivitas kerja karyawan perusahaan dapat dikelompokkan pada dua golongan, yaitu:

a. Menyangkut lingkungan kerja (teknologi dan cara produksi, sarana dan peralatan produksi yang digunakan, tingkat keselamatan dan kesehatan kerja, serta suasana dalam lingkungan kerja itu sendiri.

b. Menyangkut kesejahteraan karyawan yang terjamin dalam sistem pengupahan dan jaminan sosial, serta jaminan kelangsungan kerja

3. Supra sarana, menyangkut tiga hal:

a. Kebijaksanaan pemerintah dibidang ekspor impor, pembatasan-pembatasan dan pengawasan, juga mempengaruhi ruang lingkup pimpinan perusahaan dan jalannya aktivitas di perusahaan.

b. Hubungan antara pengusaha dan karyawan juga mempengaruhi kegiatan-kegiatan yang dilakukan sehari-hari. Bagaimana pandangan pengusaha terhadap karyawan, sejauh mana hakhak karyawan mendapat perhatian, sejauh mana karyawan diikut sertakan dalam pembuatan kebijakan.

c. Kemampuan manajemen menggunakan sumber-sumber secara maksimal dan menciptakan sistem kerja yang optimal, akan menentukan tinggi rendahnya produktivitas kerja karyawan.

Produktivitas erat terkait dengan hasil kerja yang dicapai oleh karyawan. Hasil kerja karyawan tersebut merupakan produktivitas kerja sebagai target yang didapat melalui efektivitas kerjanya dengan melaksanakan tugas yang sesuai dengan peraturan yang ditetapkan oleh organisasi. Kemudian dalam hal ini dikemukakan beberapa faktor sebagaimana yang dinyatakan sebagai indikator dari produktivitas kerja antara lain yaitu Efektifitas Kerja dan Efisiensi Kerja.

\section{SEM (Structural Equation Modelling)}

SEM adalah sebuah evolusi dari model persamaan berganda yang dikembangkan dari prinsip ekonometri dan digabungkan dengan prinsip pengaturan dari psikologi dan sosiologi, SEM telah muncul sebagai bagian integral dari penelitian manajerial akademik. Ghozali (2008). SEM terdiri dari 2 bagian yaitu model variabel laten dan model pengukuran :

Bagian pertama yaitu model variabel laten (latent variable model) mengadaptasi model persamaan simultan pada ekonometri. Jika pada ekonometri semua variabelnya merupakan beberapa variabel terukur/teramati (measured/observed variables), maka pada model ini beberapa variabel merupakan variabel laten (latent variables yang tidak terukur secara langsung).

Sedangkan bagian kedua yang dikenal dengan model pengukuran (measurement model), menggambarkan beberapa indikator atau beberapa variabel terukur sebagai efek atau refleksi dari variabel latennya. 
Dalam praktiknya, SEM merupakan gabungan dari dua metode statistika yang terpisah yang melibatkan analisis faktor (factor analysis) yang dikembangkan dipsikologi dan psikometri dan model persamaan simultan (simultaneous equation modelling) yang dikembangkan di ekonometrika.

\section{Partial Least Square (PLS)}

PLS adalah analisis persamaan structural (SEM) berbasis varian yang secara simultan dapat melakukan pengujian model pengukuran sekaligus model struktural, dimana model pengukuran digunakan untuk uji validitas dan reliabilitas, sedangkan model struktural untuk uji kausalitas (pengujian hipotesis dengan model prediksi) (Jogiyanto, 2009). Perbedaan mendasar PLS yang merupakan SEM berbasis varian dengan LISREL atau AMOS yang berbasis kovarian adalah tujuan penggunaannya, yaitu bahwa SEM berbasis kovarian bertujuan untuk mengestimasi model untuk pengujian atau konfirmasi teori, sedangkan SEM varian bertujuan untuk memprediksi model untuk pengembangan teori (Jogiyanto, 2009).

\section{Model Indikator Refleksif Dan Formatif}

Model indikator refleksif mengasumsikan bahwa kovarian diantara pengukuran dijelaskan oleh varian yang merupakan manifestasi dari konstruk latennya (Jogiyanto, 2009). Sehingga perubahan variabel laten berpengaruh bagi perubahan indikatornya. Model ini harus memiliki konsistensi internal akibat semua ukuran indikator diasumsikan semuanya valid, namun walaupun reliabilitas (cronbach alpha) suatu konstruk akan rendah jika hanya ada sedikit indikator, tetapi validitas konstruk tidak akan berubah jika salah satu indikator dihilangkan (Ghozali, 2008).

Model indikator formatif mengasumsi bahwa pengukuran saling terikat mempengaruhi konstruk latennya, dimana makna konstruk ditentukan oleh indikator pengukuran, sehingga makna seluruh konstruk laten komposit diturunkan dari indikator pengukurannya (Jogiyanto, 2009). Pada model ini, indikator tidak saling berkorelasi sehingga ukuran konsistensi internal reliabilitas (cronbach alpha) tidak diperlukan untuk menguji reliabilitas konstruk formatif (Ghozali, 2008).

\section{Model Spesifikasi Dengan PLS}

Model analisis jalur semua variabel laten dalam PLS terdiri dari 3 set hubungan, yaitu: (Ghozali, 2008)

1. Inner model, yang menspesifikasi hubungan antar variabel laten (struktural model). Model persamaannya dapat ditulis sebagai berikut:

$$
\eta=\beta_{0}+\beta_{\eta}+\Gamma \xi+\zeta
$$

Dimana $\eta$ menggmbarkan vektor endogen (dependen) variabel laten, $\xi$ adalah vector variabel laten eksogen, dan $\zeta$ adalah vector variabel residual (unexplained variance). Oleh karena PLS didesain untuk model recursive, maka hubungan antara variabel laten, setiap variabel dependen $\eta$, atau sering disebut causal chain system dari variabel laten, dapat dipesifikasikan sebagai berikut:

$$
\eta=\Sigma_{i} \beta_{j i} \eta_{i}+\Sigma_{i} \gamma_{j b} \xi_{b}+\gamma_{j}
$$

Dimana $\beta_{\mathrm{ji}}$ dan $\gamma_{\mathrm{ji}}$ adalah koefisien jalur yang menghubungkan predictor endogen dan variabel laten eksogen $\xi$ dan $\eta$ sepanjang range indeks $\mathrm{i}$ dan $\mathrm{b}$, dan $\zeta_{\mathrm{j}}$ adalah inner residual variable.

2. Outer model, mendefinisikan bagaiman setiap blok indikator berhubungan dengan variabel latennya.

Persamaan blok dengan indikator refleksif adalah sebagai berikut:

$$
\begin{aligned}
& x=\Lambda_{x} \xi+\varepsilon_{x} \\
& y=\Lambda_{y} l+\varepsilon_{y}
\end{aligned}
$$

Dimana $\mathrm{x}$ dan y adalah indikator atau variabel manifest untuk variabel laten eksogen dan endogen $\xi$ dan $\eta$. Sedangkan $\Lambda_{\mathrm{x}}$ dan $\Lambda_{\mathrm{y}}$ merupakan matrik loading yang menggambarkan koefisien regresi sederhana yang menghubungan variabel laten dengan indikatornya. Residual yang diukur dengan $\varepsilon_{\mathrm{x}}$ dan $\varepsilon_{\mathrm{y}}$ dapat diinterpolasikan sebagai kesalahan pengukuran (noise).

Blok dengan indikator formatif dapat ditulis persamaannya sebagai berikut:

$$
\begin{aligned}
& \xi=\Pi_{\xi} x+\delta_{\xi} \\
& \eta=\Pi_{\eta} y \| \delta_{\eta}
\end{aligned}
$$

Dimana $\Pi_{\xi}$ dan $\Pi_{\eta}$ adalah koefisien regresi berganda dari variabel laten dan blok indikator serta $\delta_{\mathrm{x}}$ dan $\delta_{\mathrm{y}}$ adalah residual dari regresi. 


\section{METODE PENELITIAN}

\section{Variabel}

Indikator variabel keputusan dalam penilitian adalah sebagai berikut :

a. Pengawasan Kerja $\left(\mathrm{X}_{1}\right)$

b. Disipli Kerja $\left(\mathrm{X}_{2}\right)$

Variabel keputusan merupakan suatu indikator untuk mencapai variabel tujuan. Yang mana variabel tujuan adalah Produktifitas Kerja.

\section{Metode Analisa Data}

Analisis data menggunakan software PLS versi 2.0 dengan empat tahap. Tahap pertama, melakukan pengujian model pengukuran. Tahap kedua, melakukan pengujian model struktural. Tahap ketiga, melakukan respesifikasi (revisi) model bila tidak memenuhi syarat dalam pengujian model pengukuran. Tahap keempat, melakukan pengujian hipotesis hubungan dan taraf hubungan. Berikut ini merupakan flowchart dari penelitian ini.

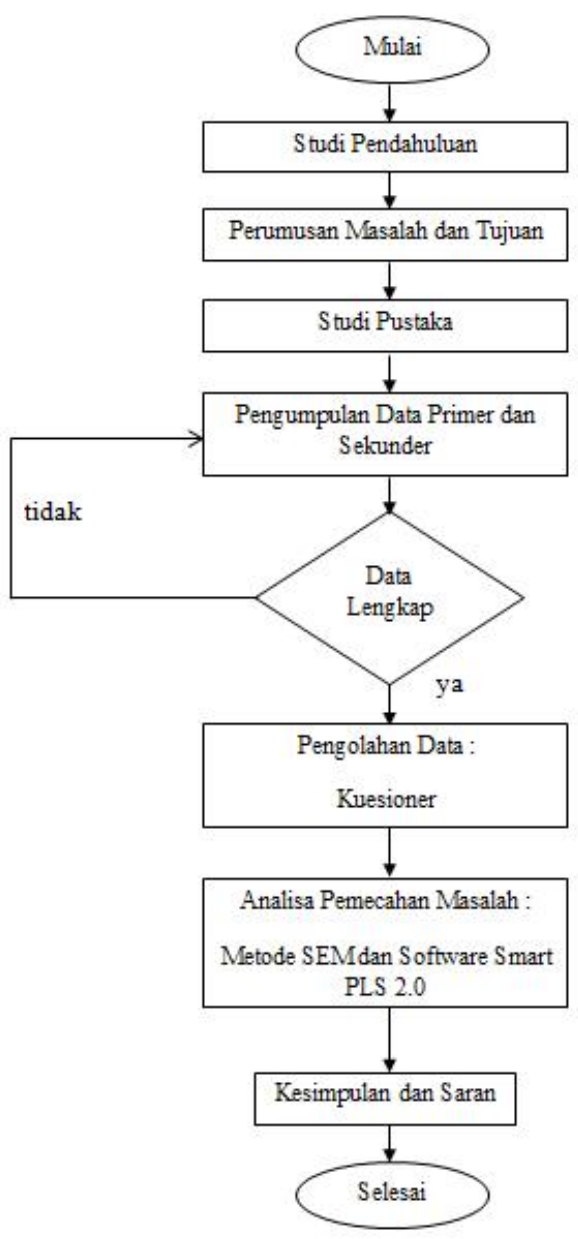

Flowchart Penelitian

\section{HASIL DAN PEMBAHASAN}

Penelitian ini menganalisis hubungan antar variabel Pengawasan Kerja dan Disiplin Kerja terhadap Produktivitas Kerja karyawan. Kajian ini difokuskan pada hubungan secara individual dari 1 variabel laten eksogen atau bebas (Pengawasan Kerja atau Disiplin Kerja) ke variabel laten endogen atau tidak bebas (Produktivitas Kerja), gabungan 2 variabel laten eksogen atau bebas (Pengawasan Kerja dan Disiplin Kerja) terhadap variabel laten endogennya atau tidak bebas (Produktivitas Kerja).

Dalam kaitannya dengan hal diatas, hipotesis yang diteliti dalam penelitian adalah sebagai berikut:

1. Hubungan Pengawasan Kerja terhadap Produktivitas Kerja 
$\mathrm{H}_{0} \quad$ : Pengawasan Kerja tidak berpengaruh yang signifikan terhadap Produktivitas Kerja;

$\mathrm{H}_{\text {alt-1 }} \quad$ : Pengawasan Kerja berpengaruh positif yang signifikan terhadap Produktivitas Kerja;

2. Hubungan Disiplin Kerja terhadap Produktivitas Kerja

$\mathrm{H}_{0} \quad$ : Disiplin Kerja tidak berpengaruh yang signifikan terhadap Produktivitas Kerja;

$\mathrm{H}_{\text {alt-2 }} \quad$ : Disiplin Kerja berpengaruh positif yang signifikan terhadap Produktivitas Kerja;

\section{Pemeriksaan Model Awal}

Pemeriksaan terhadap hasil pengolahan data yang menggunakan software SmartPLS 2.0 dikelompokkan dalam 2 kategori, yaitu:

1. Evaluasi model pengukuran (outer model), yang mencakup uji validitas dan reliabilitas indikator variabel laten pada model penelitian.

a. Uji Validitas Model Awal, yang berdasarkan pada nilai dari 2 statistik uji yaitu loading factor (diatas 0,50; T Statistics > 1,96) dan Average Variance Extracted (AVE > 0,50).

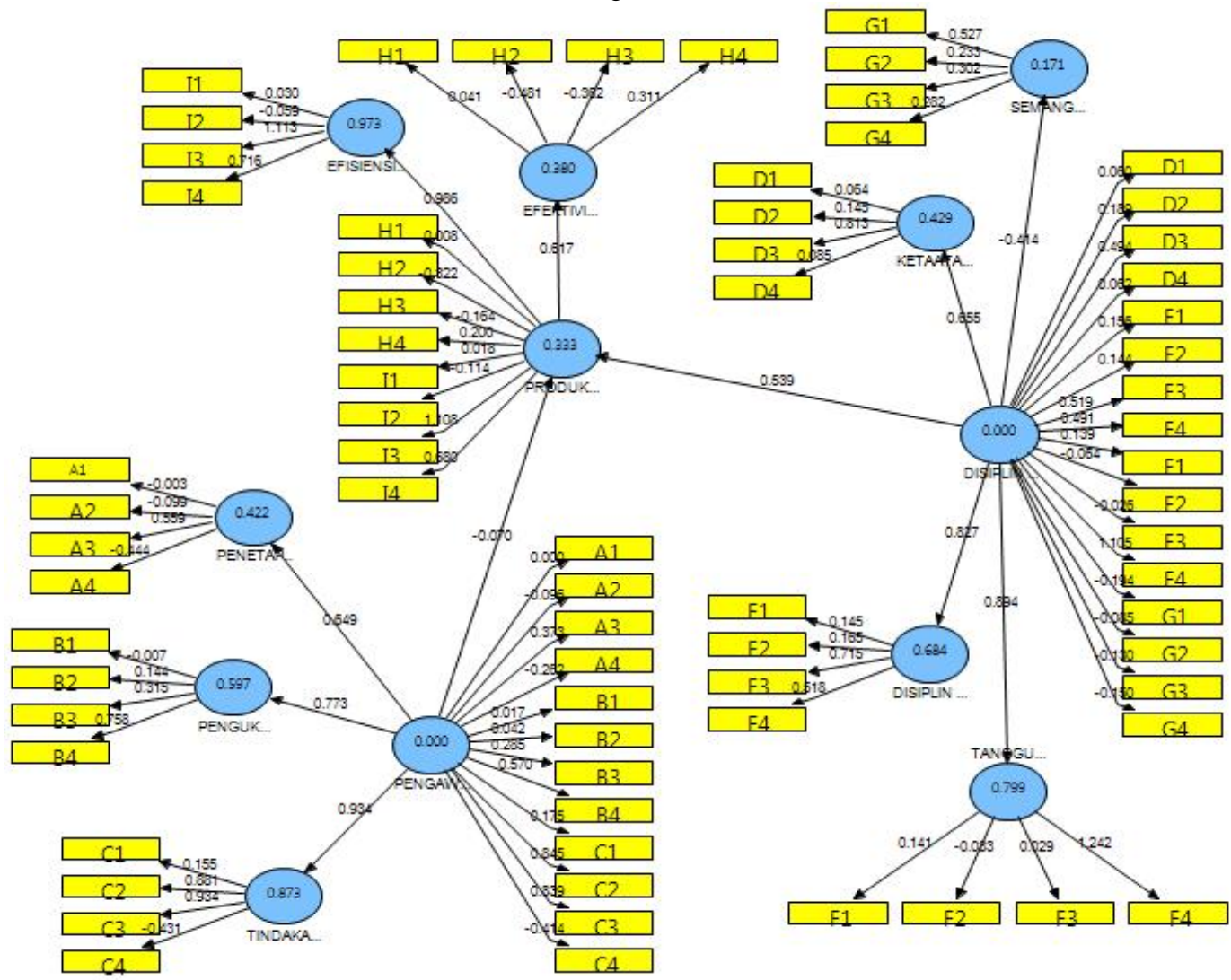

Model Awal Versi SmartPLS dan Loading Factor

Outer Loadings (Mean, STDEV, T-Values)

Loading Factor (Original Sample) dan Tingkat Signifikansinya (T Statistics) dari Second Order Model Awal

\begin{tabular}{|c|c|c|c|c|c|c|}
\hline & $\begin{array}{l}\text { Original } \\
\text { Sample } \\
(\text { (O) }\end{array}$ & $\begin{array}{c}\text { Sample } \\
\text { Mean (M) }\end{array}$ & $\begin{array}{l}\text { Standard } \\
\text { Deviation } \\
\text { (STDEV) }\end{array}$ & $\begin{array}{c}\text { Standard } \\
\text { Error } \\
\text { (STERR) }\end{array}$ & $\begin{array}{c}\text { T Statistics } \\
\text { (|O/STERR|) }\end{array}$ & Ket \\
\hline $\begin{array}{c}\text { A1 <- Penetapan Standar } \\
\text { Kerja }\end{array}$ & -0.002810 & 0.007526 & 0.168752 & 0.168752 & 0.016653 & $\begin{array}{l}\text { Tidak } \\
\text { Valid }\end{array}$ \\
\hline $\begin{array}{c}\text { A2 <- Penetapan Standar } \\
\text { Kerja }\end{array}$ & -0.098596 & -0.082582 & 0.080214 & 0.080214 & 1.229155 & $\begin{array}{l}\text { Tidak } \\
\text { Valid }\end{array}$ \\
\hline $\begin{array}{c}\text { A3 }<\text { - Penetapan Standar } \\
\text { Kerja }\end{array}$ & 0.558853 & 0.545834 & 0.089769 & 0.089769 & 6.225440 & $\begin{array}{l}\text { Tidak } \\
\text { Valid }\end{array}$ \\
\hline
\end{tabular}




\begin{tabular}{|c|c|c|c|c|c|c|}
\hline & $\begin{array}{l}\text { Original } \\
\text { Sample } \\
(\mathbf{O})\end{array}$ & $\begin{array}{c}\text { Sample } \\
\text { Mean }(M)\end{array}$ & $\begin{array}{l}\text { Standard } \\
\text { Deviation } \\
\text { (STDEV) }\end{array}$ & $\begin{array}{l}\text { Standard } \\
\text { Error } \\
\text { (STERR) }\end{array}$ & $\begin{array}{c}\text { T Statistics } \\
\text { (|O/STERR|) }\end{array}$ & Ket \\
\hline $\begin{array}{c}\text { A4 <- Penetapan Standar } \\
\text { Kerja }\end{array}$ & -0.443737 & -0.413078 & 0.143776 & 0.143776 & 3.086301 & $\begin{array}{l}\text { Tidak } \\
\text { Valid }\end{array}$ \\
\hline B1 <- Pengukuran Hasil Kerja & -0.006925 & -0.023799 & 0.081241 & 0.081241 & 0.085243 & $\begin{array}{l}\text { Tidak } \\
\text { Valid }\end{array}$ \\
\hline B2 <- Pengukuran Hasil Kerja & 0.144141 & 0.124675 & 0.093260 & 0.093260 & 1.545578 & $\begin{array}{l}\text { Tidak } \\
\text { Valid }\end{array}$ \\
\hline B3 <- Pengukuran Hasil Kerja & 0.314697 & 0.299959 & 0.103123 & 0.103123 & 3.051659 & $\begin{array}{l}\text { Tidak } \\
\text { Valid }\end{array}$ \\
\hline B4 <- Pengukuran Hasil Kerja & 0.758158 & 0.750912 & 0.067220 & 0.067220 & 11.278790 & Valid \\
\hline $\begin{array}{c}\text { C1 <- Tindakan Koreksi/ } \\
\text { Perbaikan }\end{array}$ & 0.155373 & 0.154123 & 0.069848 & 0.069848 & 2.224437 & $\begin{array}{l}\text { Tidak } \\
\text { Valid }\end{array}$ \\
\hline $\begin{array}{c}\text { C2 <- Tindakan Koreksi/ } \\
\text { Perbaikan }\end{array}$ & 0.880625 & 0.881089 & 0.110075 & 0.110075 & 8.000212 & Valid \\
\hline $\begin{array}{c}\text { C3 <- Tindakan Koreksi/ } \\
\text { Perbaikan }\end{array}$ & 0.933904 & 0.931077 & 0.111441 & 0.111441 & 8.380283 & Valid \\
\hline $\begin{array}{c}\text { C4 <- Tindakan Koreksi/ } \\
\text { Perbaikan }\end{array}$ & -0.430656 & -0.432204 & 0.057245 & 0.057245 & 7.523019 & $\begin{array}{l}\text { Tidak } \\
\text { Valid }\end{array}$ \\
\hline $\begin{array}{c}\text { D1 <- Ketaatan Dan Kesetiaan } \\
\text { Dalam Melaksanakan } \\
\text { Pekerjaan }\end{array}$ & 0.064130 & 0.073995 & 0.074809 & 0.074809 & 0.857250 & $\begin{array}{l}\text { Tidak } \\
\text { Valid }\end{array}$ \\
\hline $\begin{array}{c}\text { D2 <- Ketaatan Dan Kesetiaan } \\
\text { Dalam Melaksanakan } \\
\text { Pekerjaan } \\
\end{array}$ & 0.145010 & 0.198971 & 0.240958 & 0.240958 & 0.601807 & $\begin{array}{l}\text { Tidak } \\
\text { Valid }\end{array}$ \\
\hline $\begin{array}{c}\text { D3 <- Ketaatan Dan Kesetiaan } \\
\text { Dalam Melaksanakan } \\
\text { Pekerjaan } \\
\end{array}$ & 0.813271 & 0.738911 & 0.218744 & 0.218744 & 3.717906 & Valid \\
\hline $\begin{array}{c}\text { D4 <- Ketaatan Dan Kesetiaan } \\
\text { Dalam Melaksanakan } \\
\text { Pekerjaan } \\
\end{array}$ & 0.084950 & 0.095126 & 0.099223 & 0.099223 & 0.856154 & $\begin{array}{l}\text { Tidak } \\
\text { Valid }\end{array}$ \\
\hline E1 <- Disiplin Waktu & 0.144898 & 0.151217 & 0.057434 & 0.057434 & 2.522864 & $\begin{array}{l}\text { Tidak } \\
\text { Valid }\end{array}$ \\
\hline E2 <- Disiplin Waktu & 0.164523 & 0.174797 & 0.116035 & 0.116035 & 1.417867 & $\begin{array}{l}\text { Tidak } \\
\text { Valid }\end{array}$ \\
\hline E3 <- Disiplin Waktu & 0.715482 & 0.693645 & 0.111531 & 0.111531 & 6.415077 & Valid \\
\hline E4 <- Disiplin Waktu & 0.517550 & 0.511499 & 0.101578 & 0.101578 & 5.095122 & Valid \\
\hline F1 <- Tanggung Jawab & 0.141005 & 0.149633 & 0.074945 & 0.074945 & 1.881444 & $\begin{array}{l}\text { Tidak } \\
\text { Valid }\end{array}$ \\
\hline F2 <- Tanggung Jawab & -0.032636 & -0.029261 & 0.068721 & 0.068721 & 0.474899 & $\begin{array}{l}\text { Tidak } \\
\text { Valid }\end{array}$ \\
\hline F3 <- Tanggung Jawab & 0.028827 & 0.025471 & 0.061935 & 0.061935 & 0.465449 & $\begin{array}{l}\text { Tidak } \\
\text { Valid }\end{array}$ \\
\hline F4 <- Tanggung Jawab & 1.241565 & 1.227902 & 0.077560 & 0.077560 & 16.007814 & Valid \\
\hline G1 <- Semangat Kerja & 0.526732 & 0.235420 & 0.434274 & 0.434274 & 1.212901 & Valid \\
\hline G2 <- Semangat Kerja & 0.233459 & 0.108238 & 0.220081 & 0.220081 & 1.060785 & $\begin{array}{l}\text { Tidak } \\
\text { Valid }\end{array}$ \\
\hline G3 <- Semangat Kerja & 0.301782 & 0.145570 & 0.259405 & 0.259405 & 1.163363 & $\begin{array}{l}\text { Tidak } \\
\text { Valid }\end{array}$ \\
\hline G4 <- Semangat Kerja & 0.282362 & 0.066154 & 0.305565 & 0.305565 & 0.924063 & $\begin{array}{l}\text { Tidak } \\
\text { Valid }\end{array}$ \\
\hline H1 <- Efektivitas Kerja & 0.041076 & 0.053898 & 0.080203 & 0.080203 & 0.512145 & $\begin{array}{l}\text { Tidak } \\
\text { Valid }\end{array}$ \\
\hline H2 <- Efektivitas Kerja & -0.481033 & -0.354075 & 0.301153 & 0.301153 & 1.597304 & $\begin{array}{l}\text { Tidak } \\
\text { Valid }\end{array}$ \\
\hline
\end{tabular}




\begin{tabular}{|c|c|c|c|c|c|c|}
\hline & $\begin{array}{c}\text { Original } \\
\text { Sample } \\
(\mathbf{O})\end{array}$ & $\begin{array}{c}\text { Sample } \\
\text { Mean (M) }\end{array}$ & $\begin{array}{c}\text { Standard } \\
\text { Deviation } \\
\text { (STDEV) }\end{array}$ & $\begin{array}{c}\text { Standard } \\
\text { Error } \\
\text { (STERR) }\end{array}$ & $\begin{array}{c}\text { T Statistics } \\
(\text { (O/STERR) }\end{array}$ & Ket \\
\hline H3 <- Efektivitas Kerja & -0.361679 & -0.252722 & 0.242517 & 0.242517 & 1.491353 & $\begin{array}{c}\text { Tidak } \\
\text { Valid }\end{array}$ \\
\hline H4 <- Efektivitas Kerja & 0.311127 & 0.265149 & 0.200095 & 0.200095 & 1.554898 & $\begin{array}{c}\text { Tidak } \\
\text { Valid }\end{array}$ \\
\hline I1 <- Efisiensi Kerja & 0.029573 & 0.025846 & 0.085007 & 0.085007 & 0.347891 & $\begin{array}{c}\text { Tidak } \\
\text { Valid }\end{array}$ \\
\hline I2 <- Efisiensi Kerja & -0.058631 & -0.068367 & 0.107758 & 0.107758 & 0.544100 & $\begin{array}{c}\text { Tidak } \\
\text { Valid }\end{array}$ \\
\hline I3 <- Efisiensi Kerja & 1.112560 & 1.114293 & 0.077035 & 0.077035 & 14.442276 & Valid \\
\hline I4 <- Efisiensi Kerja & 0.715763 & 0.696441 & 0.147453 & 0.147453 & 4.854182 & Valid \\
\hline \hline
\end{tabular}

Path Coefficients (Mean, STDEV, T-Values)

Loading Factor (Original Sample) dan Tingkat Signifikansinya (T Statistics) dari First Order Model Awal

\begin{tabular}{|c|c|c|c|c|c|c|}
\hline & $\frac{\text { Original }}{\text { Sample }(\mathbf{O})}$ & $\begin{array}{c}\text { Sample } \\
\text { Mean (M) }\end{array}$ & $\begin{array}{l}\text { Standard } \\
\text { Deviation } \\
\text { (STDEV) }\end{array}$ & $\begin{array}{l}\text { Standard } \\
\text { Error } \\
\text { (STERR) }\end{array}$ & $\begin{array}{l}\text { T Statistics } \\
\text { (|O/STERR|) }\end{array}$ & Ket \\
\hline $\begin{array}{c}\text { Disiplin Kerja -> Disiplin } \\
\text { Waktu }\end{array}$ & 0.827285 & 0.828890 & 0.047727 & 0.047727 & 17.333854 & Valid \\
\hline $\begin{array}{c}\text { Disiplin Kerja -> } \\
\text { Ketaatan Dan Kesetiaan } \\
\text { Dalam Melaksanakan } \\
\text { Pekerjaan }\end{array}$ & 0.654788 & 0.682709 & 0.052662 & 0.052662 & 12.433735 & Valid \\
\hline $\begin{array}{l}\text { Disiplin Kerja -> } \\
\text { Semangat Kerja }\end{array}$ & -0.413919 & -0.183484 & 0.421219 & 0.421219 & 0.982669 & $\begin{array}{l}\text { Tidak } \\
\text { Valid }\end{array}$ \\
\hline $\begin{array}{l}\text { Disiplin Kerja -> } \\
\text { Tanggung Jawab }\end{array}$ & 0.894016 & 0.890845 & 0.049556 & 0.049556 & 18.040412 & Valid \\
\hline $\begin{array}{c}\text { Pengawasan Kerja -> } \\
\text { Penetapan Standar Kerja }\end{array}$ & 0.649400 & 0.663379 & 0.055627 & 0.055627 & 11.674168 & Valid \\
\hline $\begin{array}{c}\text { Pengawasan Kerja -> } \\
\text { Pengukuran Hasil Kerja }\end{array}$ & 0.772703 & 0.783087 & 0.034903 & 0.034903 & 22.138794 & Valid \\
\hline $\begin{array}{c}\text { Pengawasan Kerja -> } \\
\text { Tindakan Koreksi/ } \\
\text { Perbaikan }\end{array}$ & 0.934446 & 0.930562 & 0.027022 & 0.027022 & 34.580490 & Valid \\
\hline $\begin{array}{c}\text { Produktivitas Kerja -> } \\
\text { Efektivitas Kerja }\end{array}$ & 0.616678 & 0.505978 & 0.389586 & 0.389586 & 1.582906 & $\begin{array}{l}\text { Tidak } \\
\text { Valid }\end{array}$ \\
\hline $\begin{array}{c}\text { Produktivitas Kerja -> } \\
\text { Efisiensi Kerja }\end{array}$ & 0.986346 & 0.985822 & 0.005832 & 0.005832 & 169.124538 & Valid \\
\hline
\end{tabular}

Nilai Average Variance Extracted (AVE) Model Awal

\begin{tabular}{|l|c||c|}
\hline & AVE & Ket \\
\hline Disiplin Waktu & 0.206959 & Tidak Valid \\
\hline Efektivitas Kerja & 0.115173 & Tidak Valid \\
\hline Efisiensi Kerja & 0.438605 & Tidak Valid \\
\hline Ketaatan Dan Kesetiaan Dalam Melaksanakan Pekerjaan & 0.173442 & Tidak Valid \\
\hline Penetapan Standar Kerja & 0.129737 & Tidak Valid \\
\hline Pengukuran Hasil Kerja & 0.173666 & Tidak Valid \\
\hline Semangat Kerja & 0.125687 & Tidak Valid \\
\hline Tanggung Jawab & 0.390816 & Tidak Valid \\
\hline Tindakan Koreksi/ Perbaikan & 0.464321 & Tidak Valid \\
\hline \hline
\end{tabular}


b. Uji Reliabilitas Model Awal Model pengukuran dikatakan reliable apabila nilai composite reliability dan Cronbachs Alpha lebih dari 0,70 .

\begin{tabular}{|l|c|c|}
\hline \multicolumn{2}{|c|}{ Composite Reliability Model Awal } & Ket \\
\hline Disiplin Kerja & Composite Reliability & Tidak Reliable \\
\hline Disiplin Waktu & 0.346531 & Tidak Reliable \\
\hline Efektivitas Kerja & 0.428575 & Tidak Reliable \\
\hline Efisiensi Kerja & 0.063652 & Tidak Reliable \\
\hline Ketaatan Dan Kesetiaan Dalam Melaksanakan Pekerjaan & 0.590442 & Tidak Reliable \\
\hline Penetapan Standar Kerja & 0.270547 & Tidak Reliable \\
\hline \hline Pengawasan Kerja & 0.000054 & Tidak Reliable \\
\hline Pengukuran Hasil Kerja & 0.359392 & Tidak Reliable \\
\hline Produktivitas Kerja & 0.307000 & Tidak Reliable \\
\hline Semangat Kerja & 0.245849 & Tidak Reliable \\
\hline Tanggung Jawab & 0.340699 & Tidak Reliable \\
\hline Tindakan Koreksi/ Perbaikan & 0.438245 & Tidak Reliable \\
\hline
\end{tabular}

2. Evaluasi model struktural (Inner Model)

\begin{tabular}{|l|c|}
\hline \multicolumn{1}{c|}{ Koefisien Determinasi (R-Square) } & Model Awal \\
\hline Disiplin Kerja & R Square \\
\hline Pengawasan Kerja & \\
\hline Produktivitas Kerja & 0.333414 \\
\hline
\end{tabular}

Path Coefficient (Mean, STDEV, T-Statistics) Model awal

\begin{tabular}{|c||c|c|c|c|c|}
\hline & $\begin{array}{c}\text { Original } \\
\text { Sample } \\
\mathbf{( O )}\end{array}$ & $\begin{array}{c}\text { Sample } \\
\text { Mean (M) }\end{array}$ & $\begin{array}{c}\text { Standard } \\
\text { Deviation } \\
\text { (STDEV) }\end{array}$ & $\begin{array}{c}\text { Standard } \\
\text { Error } \\
\text { (STERR) }\end{array}$ & $\begin{array}{c}\text { T Statistics } \\
(\mid \mathbf{O} / \text { STERR|) }\end{array}$ \\
\hline $\begin{array}{c}\text { Pengawasan Kerja -> } \\
\text { Produktivitas Kerja }\end{array}$ & -0.069932 & -0.075983 & 0.134026 & 0.134026 & 3.906668 \\
\hline $\begin{array}{c}\text { Disiplin Kerja -> } \\
\text { Produktivitas Kerja }\end{array}$ & 0.539345 & 0.533713 & 0.138058 & 0.138058 & 12.433735 \\
\hline
\end{tabular}

Uji signifikansi menggunakan nilai T tabel untuk uji 1 arah adalah $1.664(\alpha=5 \%$, df $=79)$ dimana tingkat sifnifikansi diperoleh apabila nilai $T$ statistics (Tabel 4.9) lebih besar dari nilai T tabelnya. Akan tetapi, karena model belum valid dan reliable, maka perlu dilakukan respesifikasi atau perbaikan model tersebut sebelum dianalisis lebih lanjut.

\section{Respesifikasi dan Pemeriksaan Model Penelitian (Model Revisi)}

Respesifikasi model dilakukan dengan mengeliminasi indikator-indikator yang tidak valid dan/atau variabel-variabel yang tidak reliable. Berikut ini adalah model penelitian yang direvisi setelah proses eliminasi.

1. Evaluasi model pengukuran (outer model)

a. Uji Validitas Model Revisi, yang berdasarkan pada nilai dari 2 statistik uji yaitu loading factor (diatas 0,50; T Statistics > 1,96) dan Average Variance Extracted (AVE > 0,50). 


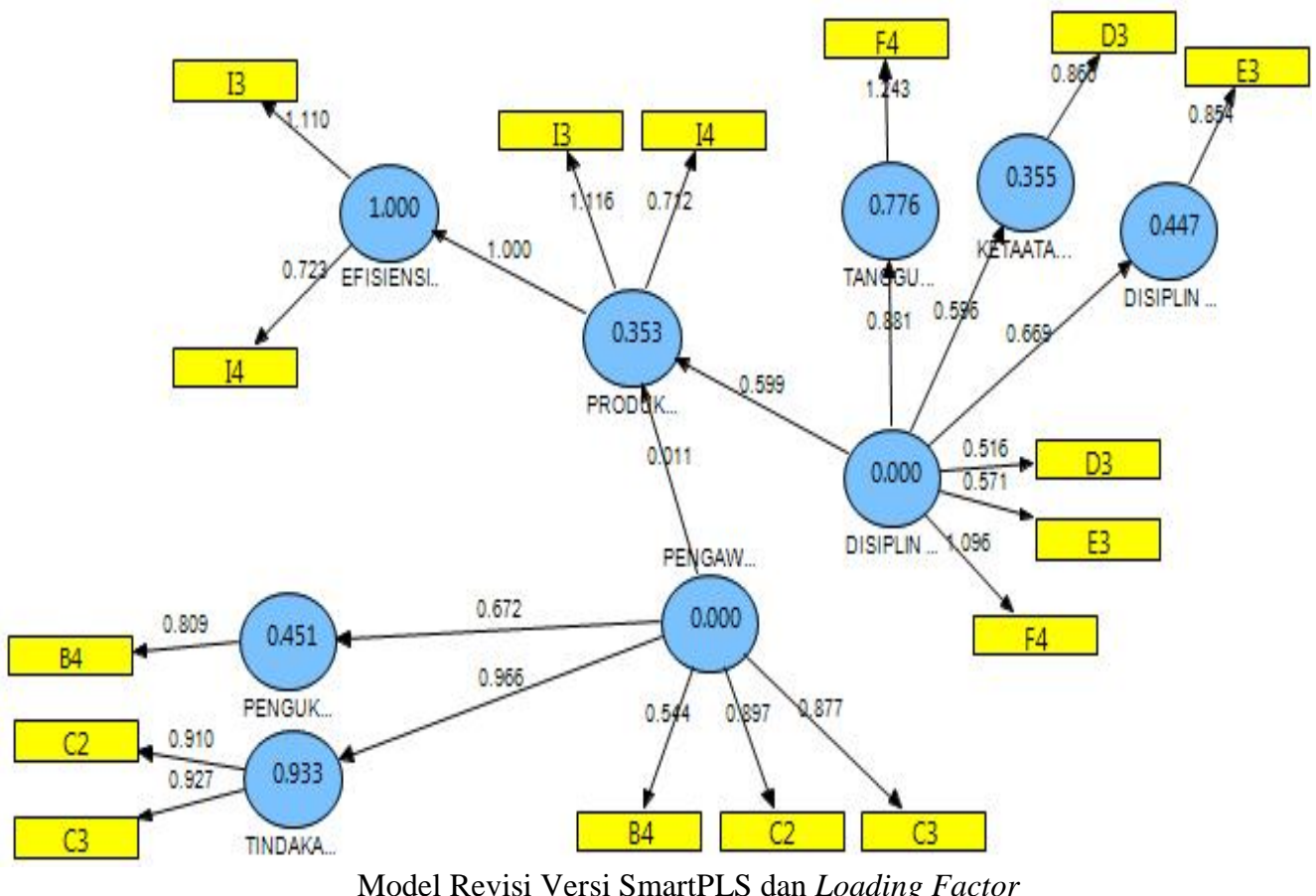

Outer Loadings (Mean, STDEV, T-Values)

Loading Factor (Original Sample) dan Tingkat Signifikansinya (T Statistics) dari Second Order Model Revisi

\begin{tabular}{|c|c|c|c||c|c|c|}
\hline & $\begin{array}{c}\text { Original } \\
\text { Sample (O) }\end{array}$ & $\begin{array}{c}\text { Sample } \\
\text { Mean (M) }\end{array}$ & $\begin{array}{c}\text { Standard } \\
\text { Deviation } \\
\text { (STDEV) }\end{array}$ & $\begin{array}{c}\text { Standard } \\
\text { Error } \\
\text { (STERR) }\end{array}$ & $\begin{array}{c}\text { T Statistics } \\
(\mid \mathbf{O S T E R R})\end{array}$ & Ket \\
\hline $\begin{array}{c}\text { B4 <- Pengukuran Hasil } \\
\text { Kerja }\end{array}$ & 0.809224 & 0.807192 & 0.043179 & 0.043179 & 18.741340 & Valid \\
\hline $\begin{array}{c}\text { C2 <- Tindakan Koreksi/ } \\
\text { Perbaikan }\end{array}$ & 0.909637 & 0.901537 & 0.104190 & 0.104190 & 8.730575 & Valid \\
\hline $\begin{array}{c}\text { C3 <- Tindakan Koreksi/ } \\
\text { Perbaikan }\end{array}$ & 0.927407 & 0.918967 & 0.109274 & 0.109274 & 8.486971 & Valid \\
\hline $\begin{array}{c}\text { D3 <- Ketaatan Dan } \\
\text { Kesetiaan Dalam }\end{array}$ & 0.865935 & 0.859544 & 0.048739 & 0.048739 & 17.766606 & Valid \\
\hline Melaksanakan Pekerjaan & 0.854309 & 0.845242 & 0.057660 & 0.057660 & 14.816330 & Valid \\
\hline E3 <- Disiplin Waktu & 1.243420 & 1.237030 & 0.078695 & 0.078695 & 15.800408 & Valid \\
\hline F4 <- Tanggung Jawab & 1.109772 & 1.106026 & 0.078917 & 0.078917 & 14.062549 & Valid \\
\hline I3 <- Efisiensi Kerja & 0.722935 & 0.717668 & 0.127769 & 0.127769 & 5.658148 & Valid \\
\hline I4 <- Efisiensi Kerja & & & & & & \\
\hline
\end{tabular}

Path Coefficients (Mean, STDEV, T-Values)

Loading Factor (Original Sample) dan Tingkat Signifikansinya (T Statistics) dari First Order Model Revisi

\begin{tabular}{|c|c|c|c|c||c|c|}
\hline & $\begin{array}{c}\text { Original } \\
\text { Sample (O) }\end{array}$ & $\begin{array}{c}\text { Sample } \\
\text { Mean (M) }\end{array}$ & $\begin{array}{c}\text { Standard } \\
\text { Deviation } \\
\text { (STDEV) }\end{array}$ & $\begin{array}{c}\text { Standard } \\
\text { Error } \\
\text { (STERR) }\end{array}$ & $\begin{array}{c}\text { T Statistics } \\
(\mid \text { O/STERR) }\end{array}$ & Ket \\
\hline $\begin{array}{c}\text { Disiplin Kerja -> Disiplin } \\
\text { Waktu }\end{array}$ & 0.668904 & 0.664090 & 0.078420 & 0.078420 & 8.529795 & Valid \\
\hline $\begin{array}{c}\text { Disiplin Kerja -> } \\
\text { Ketaatan Dan Kesetiaan } \\
\text { Dalam Melaksanakan }\end{array}$ & 0.595637 & 0.589879 & 0.105141 & 0.105141 & 5.665107 & Valid \\
\hline
\end{tabular}




\begin{tabular}{|c|c|c|c|c|c|c|}
\hline & $\begin{array}{c}\text { Original } \\
\text { Sample (O) }\end{array}$ & $\begin{array}{c}\text { Sample } \\
\text { Mean (M) }\end{array}$ & $\begin{array}{c}\text { Standard } \\
\text { Deviation } \\
\text { (STDEV) }\end{array}$ & $\begin{array}{c}\text { Standard } \\
\text { Error } \\
\text { (STERR) }\end{array}$ & $\begin{array}{c}\text { T Statistics } \\
(\text { (O/STERR|) }\end{array}$ & Ket \\
\hline Pekerjaan & & & & & & \\
\hline $\begin{array}{c}\text { Disiplin Kerja -> } \\
\text { Tanggung Jawab }\end{array}$ & 0.881190 & 0.875626 & 0.053897 & 0.053897 & 16.349607 & Valid \\
\hline $\begin{array}{c}\text { Pengawasan Kerja -> } \\
\text { Pengukuran Kerja }\end{array}$ & 0.671899 & 0.676150 & 0.056815 & 0.056815 & 11.826110 & Valid \\
\hline $\begin{array}{c}\text { Pengawasan Kerja -> } \\
\text { Tindakan Koreksi/ } \\
\text { Perbaikan }\end{array}$ & 0.965726 & 0.963128 & 0.015763 & 0.015763 & 61.263563 & Valid \\
\hline $\begin{array}{c}\text { Produktivitas Kerja -> } \\
\text { Efisiensi Kerja }\end{array}$ & 0.999833 & 0.999802 & 0.000178 & 0.000178 & 5621.024275 & Valid \\
\hline
\end{tabular}

\begin{tabular}{|l|l|l|}
\hline & AVE & Ket \\
\hline Disiplin Kerja & 0.597708 & Valid \\
\hline Disiplin Waktu & 0.729844 & Valid \\
\hline Efisiensi Kerja & 0.877114 & Valid \\
\hline $\begin{array}{l}\text { Ketaatan Dan Kesetiaan Dalam Melaksanakan } \\
\text { Pekerjaan }\end{array}$ & 0.749844 & Valid \\
\hline Pengawasan Kerja & 0.622919 & Valid \\
\hline Pengukuran Hasil Kerja & 0.654844 & Valid \\
\hline Produktivitas Kerja & 0.876742 & Valid \\
\hline Tanggung Jawab & 1.546094 & Valid \\
\hline Tindakan Koreksi/ Perbaikan & 0.843762 & Valid \\
\hline
\end{tabular}

b. Uji Reliabilitas Model Revisi

Model pengukuran dikatakan reliable apabila nilai composite reliability dan Cronbachs Alpha lebih dari 0,70 .

Composite Reliability Model Revisi

\begin{tabular}{|l|c|c|}
\hline & Composite Reliability & Ket \\
\hline Disiplin Kerja & 0.797912 & Reliable \\
\hline Disiplin Waktu & 0.729844 & Reliable \\
\hline Efisiensi Kerja & 0.931817 & Reliable \\
\hline Ketaatan Dan Kesetiaan Dalam Melaksanakan Pekerjaan & 0.749844 & Reliable \\
\hline Pengawasan Kerja & 0.826002 & Reliable \\
\hline Pengukuran Hasil Kerja & 0.654844 & Reliable \\
\hline Produktivitas Kerja & 0.931336 & Reliable \\
\hline Tanggung Jawab & 1.546094 & Reliable \\
\hline Tindakan Koreksi/ Perbaikan & 0.915254 & Reliable \\
\hline
\end{tabular}

2. Evaluasi model struktural (Inner Model)

Koefisien Determinasi (R-Square) Model Revisi

\begin{tabular}{|l|l|}
\hline & R Square \\
\hline Disiplin Kerja & \\
\hline Pengawasan Kerja & \\
\hline Produktivitas Kerja & 0.353084 \\
\hline
\end{tabular}


Path Coefficient (Mean, STDEV, T-Statistics) Model Revisi

\begin{tabular}{|c|c|c|c|c|c|}
\hline & $\begin{array}{c}\text { Original } \\
\text { Sample (O) }\end{array}$ & $\begin{array}{c}\text { Sample } \\
\text { Mean (M) }\end{array}$ & $\begin{array}{c}\text { Standard } \\
\text { Deviation } \\
\text { (STDEV) }\end{array}$ & $\begin{array}{c}\text { Standard } \\
\text { Error } \\
\text { (STERR) }\end{array}$ & $\begin{array}{c}\text { T Statistics } \\
\text { (|O/STERR) }\end{array}$ \\
\hline $\begin{array}{c}\text { Pengawasan Kerja -> } \\
\text { Produktivitas Kerja }\end{array}$ & 0.010854 & 0.019027 & 0.102599 & 0.102599 & 0.105791 \\
\hline $\begin{array}{c}\text { Disiplin Kerja -> } \\
\text { Produktivitas Kerja }\end{array}$ & 0.598593 & 0.607536 & 0.100891 & 0.100891 & 5.933063 \\
\hline
\end{tabular}

Uji signifikansi menggunakan nilai $\mathrm{T}$ tabel untuk uji 1 arah adalah $1.664(\alpha=5 \%, \mathrm{df}=79)$ dimana tingkat signifikansi diperoleh apabila nilai $T$ statistics (Tabel 4.15) lebih besar dari nilai T tabelnya. Hasil diatas menunjukkan bahwa:

1) Hipotesis Alternatif $1\left(\mathrm{H}_{\mathrm{Alt} 1}\right)$ ditolak karena T statistics $(0.105791)<\mathrm{T}$ tabel $(1.664)$;

2) Hipotesis Alternatif $2\left(\mathrm{H}_{\mathrm{Alt} 2}\right)$ diterima karena T statistics $(5.933063)>\mathrm{T}$ tabel (1.664);

Hal ini berarti terjadi perubahan model sehingga model penelitian menjadi lebih sederhana lagi seperti pada gambar dibawah ini.

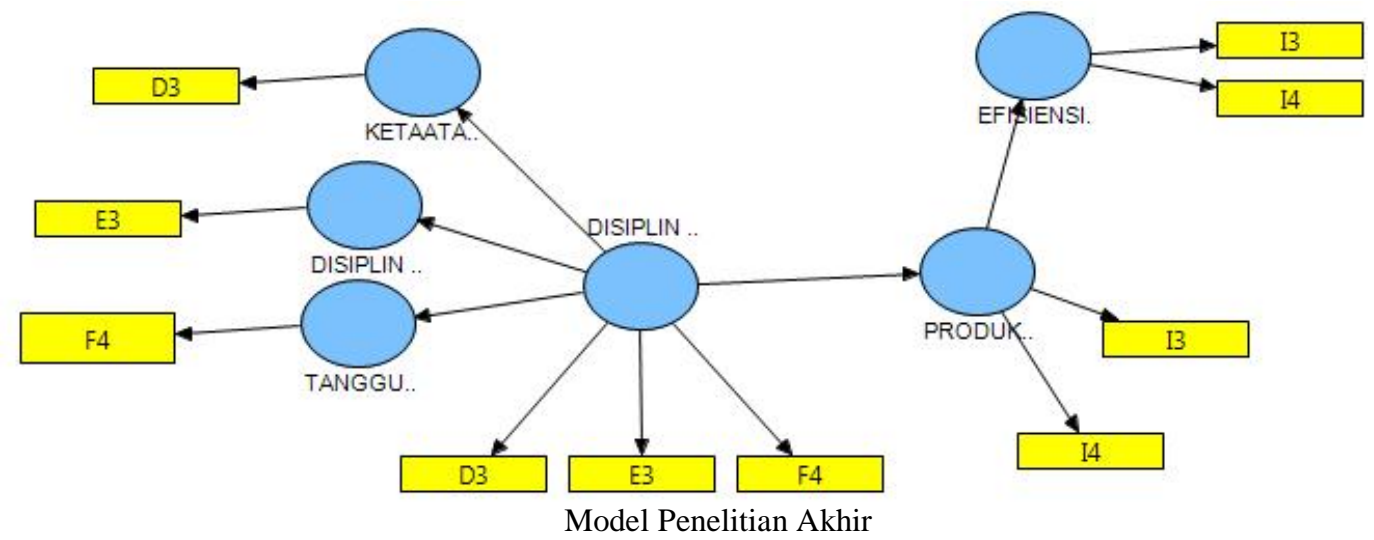

Koefisien Determinasi (R-Square) Model Revisi

\begin{tabular}{|l|l|}
\hline & R Square \\
\hline Disiplin Kerja & \\
\hline Disiplin Waktu & 0.447420 \\
\hline Tanggung Jawab & 0.776513 \\
\hline $\begin{array}{l}\text { Ketaatan Dan Kesetiaan Dalam Melaksanakan } \\
\text { Pekerjaan }\end{array}$ & 0.354766 \\
\hline Produktivitas Kerja & 0.353117 \\
\hline Efisiensi Kerja & 0.999650 \\
\hline
\end{tabular}

\section{Analisis Model Pengukuran}

Hasil pengolahan data variabel dari model awal penelitian menunjukkan keragaman kualitas variabel laten secara individual. Fenomena ini timbul karena sebagian variabel manifest (indikator) dari model second order tidak menunjukkan hasil uji (validitas dan realiabiitas) yang baik. Hal tersebut berpengaruh secara simultan untuk menciptakan kualitas rendah dari model first order.

Fenomena diatas sangat baik ditunjukkan oleh relasi variabel Pengawasan Kerja dan para indikatornya. Ketidakvalidan individual (loading factor < 0.50) dalam relasi indikator A1, A2, A3, A4, B1, B2, B3, C1 dan C4 terhadap variabel laten model second order berkontribusi pada ketidakvalidan secara komposit (gabungan) dari variabel latennya (VE < 0.50), yang mana secara simultan membuat variabel laten model first order menjadi tidak valid dan tidak reliable.

Pola yang mirip juga berlaku pada relasi variabel Disiplin Kerja dan Produktivitas Kerja dengan indikator model second dan first order-nya. Pada Disiplin Kerja, kontributor ketidakvalidan adalah indikator D1, D2, D4, E1, E2, F1, F2, F3, G2, G3 dan G4. Beberapa indikator seperti H1, H2, H3, H4, I1 dan 2 merupakan kontributor ketidakvalidan variabel Produktivitas Kerja. Secara komposit (gabungan), 
variabel Efektivitas Kerja (model first order) tidak dapat menjadi indikator dari variabel Produktivitas Kerja sebagai akibat semua indikator model second order-nya tidak valid.

Hasil analisis model pengukuran pada model awal ini menunjukkan bahwa variabel laten hanya terukur oleh sebagai indikator. Pengawasan Kerja hanya dapat dinilai dari:

a. Pengukuran Hasil Kerja, yang terukur berdasarkan

$>$ kesesuaian waktu penyelesaian pekerjaan dengan standar kerja bagi karyawan (B4);

b. Tindakan Koreksi/Perbaikan, yang terukur berdasarkan

$>$ ada tidaknya sanksi atau teguran yang diberikan bagi karyawan apabila ada kesalahan (C2);

$>$ penurunan tingkat kesalahan akibat adanya sanksi atau teguran (C3).

Disiplin Kerja hanya dapat dinilai dari:

a. Ketaatan dan Kesetiaan dalam Melaksanakan Pekerjaan, yang terukur berdasarkan tingkat penggunaan jam istirahat untuk penyelesaian pekerjaan karyawan (D3);

b. Disiplin Waktu, yang terukur berdasarkan tingkat keterbatasan waktu penyelesaian pekerjaan (E3);

c. Tanggung Jawab, yang terukur berdasarkan kesesuaian gaji dengan beban kreja dan tanggungjawab (F4);

Produktivitas Kerja hanya dapat dinilai dari Efisiensi Kerja, yang terukur berdasarkan

a. Usaha karyawan untuk menyelesaikan pekerjaan sesegera mungkin (I3);

b. Sikap karyawan dalam menyelesaikan pekerjaan yang diterima (I4).

\section{Analisis Model Struktural}

Relasi antar variabel laten dalam model awal menunjukkan kemampuan yang lemah dari kombinasi variabel laten eksogen (Pengawasan Kerja dan Disiplin Kerja) untuk memprediksi variabel endogennya (Produktivitas Kerja). Penyebab utama adalah tidak signifikannya hubungan variabel Pengawasan Kerja terhadap Produktivitas Kerja (nilai $T$ Statistisc $<\mathrm{T}$ tabel), sehingga Hipotesis Alternatif $1\left(\mathrm{H}_{\mathrm{Alt} 1}\right)$ tidak terbukti atau ditolak (terima $\mathrm{H}_{0}$ ), artinya Pengawasan Kerja tidak berpangaruh sama sekali terhadap Produktivitas Kerja karyawan PT. PLN (Persero) Rayon Ambon Kota. Hal ini lebih diakibatkan oleh kualitas model pengukurannya yang rendah. Dampak yang ditimbulkan adalah cukup rendah pengaruh komposit atau bersama dari gabungan variabel Kesempatan Kerja dan Disiplin Kerja terhadap Produktivitas Kerja $\left(\mathrm{R}^{2}=0,353084\right)$.

Kemampuan prediksi yang lebih baik bagi variabel Produktivitas Kerja hanya ditunjukkan oleh variabel Disiplin Kerja. Nilai T Statistisc yang lebih besar dari nilai T tabelnya menyatakan variabel Disiplin Kerja signifikan berpengaruh positif terhadap variabel Produktivitas Kerja. Akan tetapi Perbaikan terhadap model penelitian yang awal menjadi model revisi hanya menunjukkan perubahan yang sangat kecil terhadap taraf atau tingkat pengaruhnya, yaitu berubah dari 0,353084 menjadi 0,353117 atau naik 0,000037 poin (naik 0,009346\%). Hal ini berarti Disiplin Kerja hanya mampu menerangkan $35,3117 \%$ dari keragaman yang terjadi pada Produktivitas Kerja karyawan dan 64,6883\% lainnya akan diterangkan oleh variabel-variabel lain yang belum diketahui. Tingkat pengaruh variabel Disiplin Kerja adalah cukup dominan, artinya keragaman nilai Produktivitas Kerja cukup dominan diprediksi menggunakan nilai Disiplin Kerja. Dengan demikian, Hipotesis Alternatif $2\left(\mathrm{H}_{\mathrm{Alt} 2}\right)$ terbukti atau diterima secara signifikan (tolak $\mathrm{H}_{0}$ ).

\section{Implikasi Bagi Perusahaan}

Model revisi hasil penelitian skripsi ini membutuhkan perhatian yang seksama untuk diterapkan di PT. PLN (Persero) Rayon Ambon Kota. Pengukuran tingkat Produktivitas Kerja karyawan berdasarkan tingkat Efisiensi Kerja yang mereka tunjukkan dalam melaksanakan pekerjaan hanya dapat dilakukan apabila adanya konsistensi dan peningkatan pencapaian Efektivitas Kerja mereka. Artinya telah terjamin bahwa:

a. Pekerjaan yang dilakukan telah memenuhi pencapaian kualitas kerja yang baik;

b. Karyawan merasa puas dengan hasil pekerjaan yang dikerjakannya;

c. Pencapaian hasil kerja sesuai dengan rencana organisasi;

d. Karyawan memenuhi target waktu yang telah ditentukan dalam pekerjaan sebagai standar waktu penyelesaian terlama dari setiap pekerjaan.

Tingkat Efisiensi Kerja karyawan perlu memperhatikan beberapa hal, yaitu:

a. Tingkat keahlian dan ketrampilan karyawan agar mampu menyelesaikan pekerjaan secepat mungkin.

b. Sikap dalam bekerja yang ditunjukkan karyawan pada dasarnya merefleksikan motivasi, kesungguhan dan kenyamanan mereka dalam bekerja.

c. Karakteristik pekerjaan dan ketersediaan sarana dan prasarana. 
Dalam rangka menjadikan aspek Disiplin Kerja sebagai prediktor terbaik bagi tingkat Produktivitas Kerja Karyawan, pihak perusahaan perlu menjamin dan meningkatkan hal-hal yang berkaitan dengan mentalitas karyawan. Untuk beberapa hal yang perlu diperhatikan sebagai berikut:

a. Penggunaan jam istirahat untuk menyelesaikan pekerjaan bagi perusahaan mungkin hal yang baik, namun dalam jangka panjang dapat mengganggu kesehatan karyawan, baik fisik maupun mental. Untuk meningkatkan tingkat Ketaatan dan Kesetiaan Dalam Melaksanakan Pekerjaan, pihak manajemen perusahaan penting meninjau kembali:

b. Manajemen waktu kerja agar lebih baik sehingga dalam prakteknya, waktu kerja yang ditetapkan perusahaan lebih realistis dan akurat. Dengan demikian, karyawan tidak perlu menggunakan waktu ekstra di luar jam kerja ataupun penggunaan waktu istirahat guna menyelesaikan pekerjaan yang diembannya dan mewujudkan Disiplin Waktu yang lebih baik;

c. Meningkatkan kesadaran setiap pekerja tentang kesesuaian beban kerja dan kompensasi finansial (gaji) yang mereka terima. Aspek ini berkaitan dengan tingkat kesejahteraan karyawan, yang pada dasarnya menjadi salah satu isu sentral bagi karyawan PT. PLN (Persero) Rayon Ambon Kota. Berkaitan dengan poin a dan b diatas, maka pentingnya bagi perusahaan untuk menjalankan program insentif selain gaji bagi karyawan seperti tunjangan untuk prestasi kerja (lebih banyak bonus), meningkatkan gaji pokok, ataupun promosi jabatan berbasis prestasi/kinerja;

d. Kendati dari aspek Semangat Kerja tidak terbukti menjadi ukuran Disiplin Kerja, namun perlu dipertahankan kondisi saat ini atau bahkan ditingkatkan. Hal ini diakibatkan adanya kecenderungan harapan karyawan akan penghargaan secara finansial sebagaimana yang ditunjukkan pada poin c diatas. Dengan kata lain, selama menggunakan skema gaji dan insentif saat ini, maka secara alamiah Semangat Kerja mereka tidak akan berpengaruh secara signifikan bagi dinamika tingkat Disiplin Kerja karyawan.

\section{KESIMPULAN}

Berdasarkan penelitian diatas, maka dapat disimpulkan bahwa:

1. Pegawasan Kerja tidak memberikan pegaruh yang signifikan terhadap Produktivitas Kerja karywan PT. PLN (Persero) Rayon Ambon Kota;

2. Disiplin Kerja memberikan pegaruh positif yang signifikan terhadap Produktivitas Kerja karywan PT. PLN (Persero) Rayon Ambon Kota dimana disiplin kerja dapat menerangkan 35,3117\% dari keragaman Produktivitas Kerja karywan PT. PLN (Persero) Rayon Ambon Kota, sehingga menjadikan variabel Disiplin Kerja sebagai prediktor yang cukup dominan bagi variabel Produktivitas Kerja karyawan di perusahaan ini.I

\section{DAFTAR PUSTAKA}

Ani Fauziah, (2006)., Pengaruh Pengawasan Kerja Dan Disiplin Kerja Terhadap Produktivitas kerja karyawan Bagian Produksi Pelintingan Di Perusahaan Rokok Kretek Sukun MC Wartono Kudus

Arfida, (2003)., Ekonomi Sumber Daya Manusia . Ghalia Indonesia Jakarta

Elva Nursiva, (2012)., Pengaruh Motivasi Pengawasan Dan Budaya Kerja Terhadap Produktivitas Kerja. (Survei Pada Karyawan Bank BRI Syariah Cabang Cirebon.

Endah Inawati, (2002)., Pengaruh Pengawasan Terhadap Produktivtas Kerja Pegawai Inspektorat Kabupaten Tulungagung.

Ernita Sari Nababan, (2012)., Pengaruh pengawasan Terhadap Produktivitas Kerja Pegawai. (Study Pada Dinas Tata Ruang Perumahan Dan Permukiman Kota Binjai.

Ghozali, I. (2008)., "Structural equation modeling: metode alternative dengan partial least square (PLS)", Universitas Diponegoro, Semarang.

G.R Terry Dalam Buku AA. Anwar Prabu Mangkunegara 2007 Evaluasi Kinerja Sumber Daya Manusia, Bandung. PT Revika Aditama.

Hani Handoko, (2014)., Manajemen Personalia dan Sumber Daya Manusia, Penerbit BPFEYOKYAKARTA Edisi Kedua.

Handoko TH. (2004)., Manajemen Edisi Kedua - yokyakarta : BPFE yokyakarta

Hasibuan Melayu, (2007). , Manajemen Dasar, pengertian Dan Masalah, Bumi Aksara, Jakarta.

Henry Simamora, (2004)., Manajemen Sumber Daya manusia. Edisi Ketiga Yogyakarta STIE YKPN

Herdin Danuriatmaja, (2012)., Pengaruh Pengawasan Dan Kedisiplinan Terhadap Produktivitas Kerja Karyawan Pada PT Efatama Bomeo. Abadi Di Kota Samarindah.

Imam Ghozali dan Fuad. (2008)., Structural Equation Modeling. Semarang: Badan Penerbit Universitas Diponegoro. 
Jogiyanto, HM., (2009)., Konsep dan aplikasi PLS (partial least square) untuk penelitian empiris, Edisi Pertama, Cetakan Pertama, BPFE-Yogyakarta, Yogyakarta.

Kadarman Dan Udaya, (2001)., Pengantar Ilmu Manajemen, Jakarta

Lia Viktoria ,(2012) Pengaruh Pengawasan Terhadap Produktivitas Kerja Pegawai Depertemen Pekerjaan Umum. (Studi Pada Direktorat Jenderal Bia Marga SNVT Perseruan Dan Pembangunan Jalan Dan Jembatan Motorpoliton Medan.

Manullang, (2002)., Manajemen Sumber Daya Manusia, Edisi-1 Yokyakarta : BPFE-Yokyakarta.

Masitah. S, (2012)., Analisah Pengaruh Kualitas Kepemimpinan Dan Pengawasan Terhadap Produktivitas Kerja Karyawan Pada PT Greenteck Motorindo Pekan Baru.

Moekijat, (2001)., manajemen Tenaga kerja dan hubungan kerja Bandung: pioner Jaya

Siagian, Sondang P. (2007)., Manajemen Sumber Daya Manusia: PT Bumi Absen.

Simamora, Bilson, (2004)., Panduan Riset Perilaku Konsumen PT Gramedia Pustaka Umum : Jakarta

Simanjuntak Payaman J, (2005)., Manajemen Dan Evaluasi Kinerja,Jakarta : FE. UI

Simbolon, Maringan Masry, (2004)., Dasar Dasar Administrasi Dan Manajemen Jakarta : Ghalia Indonesia.

Sinungan, (2005)., Produktivitas Apa Kuantitatif dan kualitatif dan R dan D, Alfabeta Bandung.

Sinungan Muchdarsyah, (2005)., Produktivitas Apa dan bagaimana. Bumi Aksara : Jakarta

Sondang, (2002) Manajemen Sumber Daya Manusia Jakarta: Bumi Aksara.

Sumarsono Sony, (2003)., Ekonomi Manajemen Sumber Daya Manusia Dan Ketenagakerjaan, Graha Ilmu : Yogyakarta.

Sumarsono Sony, (2009)., Teori dan Kebijakan Publik Ekonomi Sumber Daya Manusia. Graha Ilmu: Yokyakarta.

Tohardi Ahmad, (2002), Pemahaman Praktis Manajemen Sumber Daya Manusia, Universitas Tanjung Pura, Mandar Maju, Bandung.

Wahyuni Alimuddin, (2012)., Pengaruh Kompensasi dan Pengawasan Kerja Terhadap Produktivitas Kerja Karyawan Pada PT Bakrie Telecom Rayon Makasar. 